\title{
The Impact of E-Accounting on Mexican Accounting Firms
}

\author{
Roberto Rodríguez Venegas, (Doctor in Accounting and \\ Finance.) \\ Universidad de Guanajuato, Campus Celaya Salvatierra, México.
}

\begin{abstract}
In the global economy electronic accounting, or e-accounting, is defined as any accounting system which is based on information communication technology for the capture and processing of a business' financial data. E-accounting relies mainly on computers, although it may be used on other devices. In Mexico, the concept of electronic accounting has been widened by adding the obligation to send the tax authorities the information resulting from its application. The objective of this study was to describe the impact of electronic accounting on accounting firms, as well as establish the relationship between the factors of change and compliance with the new regulations, including information submission deadlines. We applied a questionnaire to 90 accounting firms through a study of four factors: the demographic profile of the firm, the demographic profile of the general director, investment in software and training, as well as the reasons for using electronic accounting in relation to the level of compliance. The results show that the model as a whole is significant and that the investment in software and training, as well as the legal structure of the firm, are relevant factors for implementation.
\end{abstract}

Keywords: E-accounting, implementation, accounting firms

\section{Introduction}

Information has become one of the main tools for decision making in organizations (Arias, 2002). Accounting is the methodical record-keeping of the transactions of a company, and it is important in helping the company control the movement of its assets, the results of its operations, and to act at all times as a means of testing commercial performance.

Although accounting has achieved its most notable achievements in the field of business, the accounting function is vital in all sections of our society. All citizens need a certain amount of accounting knowledge if they 
wish to act in an intelligent way and accept the challenges that society imposes on them (Josar, 2001; cited in Nuñez, 2013).

For years, accounting has been considered a formal and generalized source of information within organizations (Chapellier, 1994). According to norms and regulations, accounting provides a representation of the financial situation of companies. This representation is communicated through financial statements presented at the end of each accounting period and conforms with the legal and tax requirements (Daoud \& Triki, 2013).

Mexico has been characterized by constant change. Globalization obliges the country to be permanently ready to respond to the diverse needs of organizations, which is why it is vital to constantly update financial accounting. Therefore, accountants must be able to attend to the laws for registering transactions and adequately present financial statements, which are consulted by the users who make the decisions to achieve the objectives of their organizations. Any organization, whether a company or a natural person, must understand and manage their resources in the most effective way possible, which is why they must have adequate information and accounting control (Núñez, 2013), which represents something optional for the businessperson as the administration of information internally with their accountant or an external accountant through an accounting firm.

An accounting firm is formed by a public accountant, either alone or partnered with other colleagues, where management consulting, audits, tax, and financial services are provided to the general public and to businesses. According to INEGI (2016), in Mexico there are 19,082 economic units that offer accounting and audit services, and are registered in the National Statistical Directory of Economic Units (DENUE) in which states such as Guanajuato, Jalisco, Mexico City, Veracruz, and the State of Mexico have the greatest numbers of registered economic units. It is notable that accounting firms contribute $19.7 \%$ of the economic units that offer professional, scientific, and technological services of the total GDP that the country generates, according to information provided by INEGI.

Furthermore, as Mexico is part of the Organization for Economic Cooperation and Development (OECD) and based on the recommendations made in 2012 in the document Getting It Right, a fiscal reform was put into place that directly affected public accountants because it established a set of new obligations for taxpayers that must provide accounting information electronically before the Mexican tax authority. The obligation to keep electronic books arises as a measure for the construction of a more agile fiscal system, making the base of the tax income broader and more stable, in conjunction with the use of information technologies to facilitate the adequate compliance and presentation of information based on accounting and fiscal norms. 
The fiscal reform brings with it changes in the traditional mechanism that taxpayers or their accountant do not adapt to quickly, creating obstacles that make meeting the deadlines set by the Taxpayer Administration System (SAT), the tax authority in Mexico, difficult. Generating electronic accounting implies a much greater workload in comparison to that commonly undertaken by accountants, due to the nature of this accounting, taxpayers will have to integrate all operating information of the company so that they comply with the guidelines established by the SAT. This creates a problem, the taxpayer is no longer able to comply with the requirements alone, i.e. without the help of a professional accountant who can advise them on how to comply with the requirements and how to submit the information according to the rules, while at the same time keeping up-to-date in terms of what the fiscal reform implies.

The lack of professional administration restricts the proper planning and ability to interpret economic and financial variables, the formation of the vision and mission of the company, that is lost in the day-to-day operation without a long-term vision. This generates unrealistic expectations, such as thinking that the business will develop with relative ease, or incur unnecessary expenses or investments, this is reflected in a scarce definition and planning of objectives, inconsistent cash flow with the available work capital, and even less with obtaining long-term capital (Maza, 1997). These changes directly affect the taxpayers, but also the accounting firms who must now improve all of their accounting processes in order to comply with the abovementioned specifications.

The objective of this work is to describe the impact of the fiscal reform, specifically the obligation to keep and send electronic accounting (eaccounting) in accounting firms, as well as establish cause and effect, among some factors of change and compliance with preparation and sending. The study was undertaken in three stages: some accounting firms were identified in the state of Guanajuato, Mexico. We applied a survey to members of the firms, and we analyzed the data collected. Finally, we elaborated this paper that contains the following sections: starting with the literature review; followed by the research method used to ground the findings obtained; and to be able to finalize, the conclusions made based on prior analysis and to provide recommendations for future application.

\section{Literature Review}

According to Martínez (2004), companies are found in a dynamic environment, and by changing it, the organization must adapt to said changes, modifying its behavior to confront internal and external demands. Accounting cannot be indifferent to the social, political, cultural, and environmental problems that afflict society. This obliges the professional accountant to move in interdisciplinary, dynamic, competitive, and changing environments if he 
wishes to be successful (Cifuentes, 2013), toppling the traditional paradigm of management and communication of accounting information, while at the same time reinventing the form of interrelation of individuals within social organizations (Rodríguez, 2003).

Accounting is a universal phenomenon in the modern world. Each organization or company needs to make decisions, coordinate multiple activities, direct people, and evaluate performance based on previously determined objectives. Throughout history, companies and organizations have been adapting and developing, which is why they have been subject to incessant pressure from society, among those that highlight the demand to participate in decision making, self-management, and flexible working.

Milán (2012) comments that consulting may be a source of valuable information and ideas that start initiatives, innovations, and improvements in any area of the company and help directors, managers, and any staff direct, diagnose, and resolve the problems or inconsistencies that companies tend to have (López, López, and González, 2014). The activity of the public accountant has been changing since the moment that it arose the interest of a very wide number of people from the public and private sectors, in terms of the variety of services that may be offered such as advising, accounting, audits, and consulting on fiscal and administrative subjects.

A public accountant may operate in many fields; they may work independently or in a group, such as an accounting firm, or be dependent upon another accountant through complying with a work contract, to determine the tasks that form part of the structure of the organization (Cabrera, 2010). Elizondo (2004, cited in Núñez, 2011), notes that "the professional accounting firm is where the accountant offers his services independently. It is said that the activity of the accountant is independent when either an individual or group of colleagues sets up a firm that is open to the public and freely contracts work, receiving the corresponding retribution for work through fees" (own translation).

At times, the ease of access and transmission of information for the professional accountant has meant that the volume of information is excessive. Given the economic environment in which business activities have developed, not only does it require a certain degree of knowledge about the workings of the accounting system, but also technical ICT management skills, especially relative to the knowledge and use software or packages that are capable of collecting all of the information, both external and internal, and transform them into accounting information (Méndez, 2007).

According to the most recent reforms that have been implemented in Mexico, with the objective of increasing the total amount of taxes collected and generating a more agile system, since 2014, a new requirement called electronic accounting came into place. Electronic accounting defined by the 
Mexican tax authority as the "obligation to keep accounting records and books through electronic means, and submit this accounting information monthly to the SAT" (SAT, 2016, own translation), under specific guidelines established within the fiscal norms such as the Código Tributario Mexicano (Mexican Taxpayer Code).

The international definition of electronic accounting sustains that it is any accounting system that is based on information technology for the capture and processing of financial information in companies, the most important element for electronic accounting to take place is the use of the computer, although it may be undertaken on any electronic device (Amidu, John, \& Abor, 2011; Drew, 2015).

The reform is directed towards natural persons and businesses in the general classification, in addition to the financial sector with cumulative incomes greater than or equal to 4 million pesos $(200,000$ USD at the time of writing) during the 2013 tax year and should comply with the obligation from 2015 onwards. Charities or registered non-profits, natural persons, individuals or businesses involved in farming, ranching, forestry, and fishing, natural persons who offer professional or business services, renting properties that inscribed into the federal register in 2014 and whose incomes was lower than 4 million pesos (200,000 USD at time of writing) generated in the year 2014, should send their information from the year 2016, except those natural persons who are registered in the fiscal incorporation classification (SAT, 2016). The fiscal incorporation regimen refers to micro-companies that under the current framework do not pay taxes on profit in Mexico.

Electronic record and bookkeeping may be simple for any accountant who has a commercial or integrated management software. However, issues arise when specific characteristics are required for certain documents, such as the generation of files in standardized digital formats for its adequate translation.

It is important to highlight that in the taxpayer context, sending electronic accounts only comprises of the balance to corroborate and the catalogue of accounts with the grouping codes of the SAT, in addition, the taxpayers must be able to generate electronic information from their accounting policies and assistants to submit it to the SAT (SAT, 2016).

The obligation really implies radical changes in the companies and natural persons subject to this reform must keep their books. Every accountant must interpret the new obligations so that they correctly comply with all of the new regulations, which is why there is a need to conduct research among accounting firms in the State of Guanajuato, specifically on the implementation of electronic accounting to adequately comply with regulations. All of these changes demand that accountants ask for more information from businesspeople so that it may be reconstructed and organized 
with the utmost detail according to SAT specifications, which implies a heavy and perhaps excessive administrative load for the majority of professional accountants.

The accountant should perform an active and effective role in the design process with the aim to achieve a strong internal system, as well as the needs of users of accounting information, in addition to the data necessary for decision making. On the other hand, technological advances also imply various risks related to the security and integration of electronic accounting, such as the development of computers, information and technology are not joined by a similar development in the practices and norms that they control (Okab \& Ali Al-Oqool, 2014).

We based this study on the theory of Innovation Diffusion (Rogers, 1963). The author argues that "the adoption of innovation is a process through which the individual or the unit of adoption tends to first find out about an innovation, until its adoption or rejection" (own translation). The process has five stages: knowledge, persuasion, decision, implementation, and confirmation.

Rogers identifies five groups of adoptees. The innovators or generators $(2.5 \%)$, who are the first to use the innovation in the social system, are characterized as adventurers, always anxious to experience new technologies. The first adopters (13.5\%), who are considered respectable leaders capable of influencing the behavior of others in the business as they adopt the technology because they recognize its benefits and do not need to have reliable references. They personify the concept of using new ideas successfully and with discretion. The early majority (34\%) are hesitant; they deliberate before adjusting to a completely new life, as they require having a reference of successful experiences before adopting an innovation. The late majority (34\%) are the skeptics, as they assume an air of distrust and caution towards innovation. The late majority feel uncomfortable with technology and require peer pressure to motivate adoption. The rejected (16\%) are the last to adopt an innovation, or they simply reject it. Here we include those individuals who mostly never adopt the technology. They are traditional. Their only reference is to the past, and they make their resolutions with the criteria of the previous generation (Rogers, 2003).

However, besides the above mentioned complexities, a public accountant will invariably face internal and external obstacles for the adequate compliance with the norms, such as skepticism by those involved, resistance to change, and the lack of consideration for the implications, that as an organization changes, have the following factors: structural, personal, and cultural. It should be noted that the above variables influence the method that the accounting firm opts to take in terms of electronic accounting, not forgetting the qualitative aspects that the leader or leaders of the accounting 
firm may develop, as this depends on the notion and the level of innovation that the public accountant wishes to develop.

Reaffirming, said responsibility falls to the directors and the efficacy of information, García (2005) reflects that:

"The decisions that directors make should be compatible with the quality of information used and the rationale that the manager develops the process of transformation of the information in action. As a consequence, information systems are definitive weapons for making the company more professional, helping the user satisfy their information needs" (own translation).

One of the most important variables that should be measured is the level of commitment of the maximum direction with respect to fulfilling norms and ethical standards, as traditionally this has been considered a key factor for generating a culture of compliance (Casanovas, 2013). Lendel Hittmára and Siantová (2014) establish that one must review the corporate strategy with the aim of including the innovations of product and process, assigning sufficient resources (human and financial) to innovate and seek, introducing a transparent record of innovative initiatives, establish a climate that promotes the development of innovative ideas, the creation of spaces for the open debate of ideas and innovative teamwork, create a mechanism for the selection of adequate innovative ideas in order to avoid duplicity and the loss of innovation.

Therefore, the importance of the participation of accountants in the elaboration of accounting information is derived from the fact that accountants, as users of accounting information systems be well qualified for determining the way they develop their work and needs (Okab \& Ali AlOqool, 2014). The lack of commitment from upper management makes it very difficult to obtain models of effective compliance, as their objectives will be perceived as an element of value by the firm's staff, conditioned by the conduct that the leaders observe (Casanovas, 2013).

The changes in the tasks or the established positions or routine work may also cause economic tremors if individuals are concerned about not performing new tasks or routines according to the above norms. According to publications by CONTPAQi (2016) and Microsip (2016), the main software brands in Mexico that work as a local service providers, enable compliance with accounting and fiscal norms that contain the following programs: purchases, sales, inventory, accounts receivable, accounts payable, point of sales, banks, production, payroll, and initial training, each program has an annual cost that varies from $\$ 31.00$ to $\$ 25.00$ USD approximately; the Platform of Financial and Fiscal Services (CROL PFF, 2016) software allows accounting firms to offer cloud-based fiscal and financial services, and has an 
annual cost of \$16.00 USD approximately, including all the above mentioned modules.

A study undertaken in Malaysia "Cloud Computing Awareness and Adoption Among Accounting Practitioners in Malaysia" (Tarmidi et al., 2014), mentions the participation of professionals in accounting and the expectation in terms of the diffusion of cloud computing in future, however, the modality of adoption of electronic accounting in this country is not obligatory. The factors included in this study are: area of professional accounting, ethnicity, education level, if they are a member of a professional institute, and the years of experience in the area of accounting and auditing, however, they do not include other factors that may be relevant, such as investment in software and consulting, and the legal structure of the accounting firms studied.

\section{Research Methodology}

This study has a descriptive character and the data collected were obtained from a survey that contains 17 multiple choice questions divided into four sections, applied to randomly selected sample where the questionnaire was applied after various talks with accounting firms located in the State of Guanajuato. The questionnaire makes reference to the electronic accounting obligation where accountants or leaders of firms selected the relevant answers. The sections into which the questionnaire is divided are the demographic profile of the firm and its variables, the demographic profile of the director general of the firm, investment in software and consulting, and reasons for the use of electronic accounting.

The independent variables are type of firm, age of the firm, and whether or not it is a group of colleagues, these constitute the dimension "demographic profile of firm". The variables gender, age, maximum level of education, certification, and experience in accounting comprise the dimension "demographic profile of the general director of the firm". Training of the director in electronic accounting and investment in software and consulting are components of the dimension "training and investment in software and consulting for electronic accounting". The uncertainty of working, safe information, confidential information, reduction of operating costs, fast and effective updating of software are the variables that contribute to the dimension "reasons for using electronic accounting". The dependent variables in this study are: "submitted the electronic accounting on time in 2015", "did not submit the electronic accounting on time in 2015", "did not send electronic accounting on time in 2015 ", and "they are ready to send the electronic accounting in 2016".

The results obtained were input into the statistical program SPSS (Statistical Package for Social Sciences), and the program Stata version 14 
from the company StataCorp LP, which ensured the adequate analysis of the information obtained.

\section{Results}

The demographic profiles collected found that $62.2 \%$ of the firms interviewed function under the fiscal classification of natural persons, and $59.6 \%$ have an average experience of 15 to 39 years, and $92.3 \%$ include at least one member of an accounting college (Table 1).

Table 1. Demographic profile of firms

\begin{tabular}{cccc}
\hline \hline Type & Natural persons & 56 & $(62.2 \%)$ \\
& Business & 25 & $(27.8 \%)$ \\
& Both & 9 & $(10.0 \%)$ \\
& Total & 90 & $(100 \%)$ \\
\hline Experience (years) & $1-14$ & 34 & $(38.2 \%)$ \\
Median=17.48 & $15-39$ & 53 & $(59.6 \%)$ \\
DE=10.48 & $40+$ & 2 & $(2.2 \%)$ \\
& Total & 89 & $(100 \%)$ \\
\hline Group? & No & 7 & $(7.7 \%)$ \\
& Yes & 84 & $(92.3 \%)$ \\
& Total & 91 & $(100 \%)$ \\
\hline
\end{tabular}

The majority $(80 \%)$ of the directors of the firms interviewed were male, and the average age of the director general of the firm shows that $46.9 \%$ are older than 50 and $37.5 \%$ are between 40 and 49 years of age, together they represent $84.7 \%$ of the total sample. Professional certification is considered continuous professional education and $74.7 \%$ of the respondents had obtained relevant certification. With respect to accounting experience, $68.1 \%$ have more than 20 years of experience, and $29.7 \%$ between 5 and 20 years for a total $97.8 \%$ between both categories (Table 2).

Table 2. Demographic profile of director general of firms

\begin{tabular}{cccc}
\hline \hline Gender & Female & 18 & $(19.8 \%)$ \\
& Male & 73 & $(80.2 \%)$ \\
& Total & 91 & $(100.0 \%)$ \\
\hline Age (years) & $20-29$ & 1 & $(3.1 \%)$ \\
Median=50.97 & $30-39$ & 4 & $(12.5 \%)$ \\
DE=12.87 & $40-49$ & 12 & $(37.5 \%)$ \\
& $50+$ & 15 & $(46.9 \%)$ \\
& Total & 32 & $(100.0 \%)$ \\
\hline Highest educational level & Bachelor & 36 & $(39.6 \%)$ \\
& Diploma & 3 & $(3.3 \%)$ \\
& Specialty & 9 & $(9.9 \%)$ \\
& Masters & 41 & $(45.1 \%)$ \\
& Doctorate & 2 & $(2.2 \%)$ \\
\hline
\end{tabular}




\begin{tabular}{cccc} 
& Total & 91 & $(100.0 \%)$ \\
\hline Are they certified? & No & 23 & $(25.3 \%)$ \\
& Yes & 68 & $(74.7 \%)$ \\
& Total & 91 & $(100.0 \%)$ \\
\hline Experience in accounting & $<5$ & 2 & $(2.2 \%)$ \\
& $5-20$ & 27 & $(29.7 \%)$ \\
& $20+$ & 62 & $(68.1 \%)$ \\
& Total & 91 & $(100.0 \%)$ \\
\hline
\end{tabular}

Of the directors of the firms interviewed, $92.3 \%$ of the directors have received training in electronic accounting, and in terms of the costs incurred, half have spent less than $\$ 20,000 \mathrm{MXN}$ and $37.8 \%$ have spent between $\$ 20,000$ and $\$ 39,999 \mathrm{MXN}$, which together describe $87.8 \%$ of the directors studied (Table 3).

Table 3. Training and investment in EC

\begin{tabular}{cccc}
\hline \hline The director is trained in the & No & 7 & $(7.7 \%)$ \\
EC? & Yes & 84 & $(92.3 \%)$ \\
& Total & 91 & $(100.0 \%)$ \\
\hline Investment in software and & $<20,000$ & 45 & $(50.0 \%)$ \\
consultancy for the CE & $20,000-39,999$ & 34 & $(37.8 \%)$ \\
& $40,000-79,999$ & 6 & $(6.7 \%)$ \\
$80,000-99,999$ & 3 & $(3.3 \%)$ \\
& 100,000 or more & 2 & $(2.2 \%)$ \\
& Total & 90 & $(100.0 \%)$ \\
\hline \hline
\end{tabular}

* Note: $\mathrm{CE}=$ Accounting Electronics

In terms of the reasons to use electronic accounting (69.2\%) were uncertain whether or not it would work; $57.1 \%$ indicates that the reports are reliable and they do not show differences; $48.4 \%$ of firms have problems with internet access, although the updated software that they use is fast and secure according to $39.6 \%$; and $38.5 \%$ consider that the information is safe, and $37.4 \%$ state that the information is confidential. Only $27.5 \%$ report that electronic accounting results in a reduction of operating costs (Table 4).

Table 4. Reasons to use Electronic Accounting

\begin{tabular}{ccccccc}
\hline \hline & \multicolumn{3}{c}{ Don't know } & & No & Yes \\
\hline Uncertainty that it will work & 6 & $(6.6 \%)$ & 22 & $(24.2 \%)$ & 63 & $(69.2 \%)$ \\
The information is safe & 17 & $(18.7 \%)$ & 39 & $(42.9 \%)$ & 35 & $(38.5 \%)$ \\
The information is confidential & 27 & $(29.7 \%)$ & 30 & $(33.0 \%)$ & 34 & $(37.4 \%)$ \\
Reduces operating costs & 14 & $(15.4 \%)$ & 52 & $(57.1 \%)$ & 25 & $(27.5 \%)$ \\
Software updates are fast and effective & 15 & $(16.5 \%)$ & 40 & $(44.0 \%)$ & 36 & $(39.6 \%)$ \\
The reports are reliable; they do not & 16 & $(17.6 \%)$ & 23 & $(25.3 \%)$ & 52 & $(57.1 \%)$ \\
show differences & 10 & $(11.0 \%)$ & 37 & $(40.7 \%)$ & 44 & $(48.4 \%)$ \\
Internet access is a problem & 10 & & & & &
\end{tabular}


We found a wide range of values and standard deviations, which indicates that the median is better than the mean as a measure of the central tendency. We observed that the number that submitted their accounting electronically on time in 2015 is showed the lowest median, while those that are not ready to submit the electronic accounting for 2016 had a greater median (Table 5).

Table 5. Effects of Implementing Electronic Accounting (EA)

\begin{tabular}{|c|c|c|c|c|c|c|c|c|}
\hline & \multirow[b]{2}{*}{$\begin{array}{c}\text { Rang } \\
\mathrm{e}\end{array}$} & \multirow[b]{2}{*}{$\begin{array}{l}\text { Percenti } \\
\text { le } 25\end{array}$} & \multirow[b]{2}{*}{$\begin{array}{l}\text { Medi } \\
\text { an }\end{array}$} & \multirow[b]{2}{*}{$\begin{array}{l}\text { Percenti } \\
\text { le } 75\end{array}$} & \multirow[b]{2}{*}{$\begin{array}{c}\text { Mea } \\
\mathrm{n}\end{array}$} & \multirow[b]{2}{*}{$\mathrm{DE}$} & \multicolumn{2}{|c|}{$\begin{array}{c}\text { Shapiro- } \\
\text { Wilk } \\
\end{array}$} \\
\hline & & & & & & & $\begin{array}{l}\text { Statist } \\
\text { ic }\end{array}$ & Sig \\
\hline Submitted EA on time in & $(1-$ & & & & & & & .00 \\
\hline 2015 & 20) & 2.0 & 4.0 & 6.0 & 5.5 & 5.1 & .666 & 2 \\
\hline Did not submit EA on time & $(1-$ & & & & & 32. & & .00 \\
\hline 2015 & 220) & 2.0 & 6.5 & 15.0 & 15.8 & 2 & .672 & 2 \\
\hline Are ready to submit EA in & $(1-$ & & & & & 37. & & .00 \\
\hline 2016 & 120) & 4.0 & 8.5 & 15.0 & 18.1 & 1 & .711 & 5 \\
\hline Are not ready to submit EA & $(1-$ & & & & & 18. & & .00 \\
\hline in 2016 & 95) & 3.0 & 10.0 & 20.0 & 14.8 & 1 & .631 & 1 \\
\hline
\end{tabular}

Multiple linear regression equations were calculated to predict the effects of the implementation of electronic accounting (four independent variables), the matrix of correlations was generated and analyzed for each dependent variable with respect to all the independent variables with the objective of finding those factors with a greater relationship and building the multiple linear regressions.

Following the method proposed by Field (2013), influencing cases were removed (Cook's distance $>1$, Mahalanobis' distance $>11$ ), atypical cases $(95 \%$ of the remaining standardizations within +- 2DE), multicollinearity diagnostic (tolerance $<0.2$, VIF $>10$ that suggests problems of multicollinearity) and the assumptions of the model were confirmed with homoscedasticity and linearity of the remainders. We found significant estimated regression equations for three dependent variables; Table 6 summarizes the results.

Table 6. Estimated multiple regression equations.

Sent the electronic accounting on time 2015 (VD01)
Did not send the electronic accounting on time 2015 (VD02)
Are ready to send electronic accounting 2016 (VD03)

\begin{tabular}{cccccccccc}
\hline Variable & B & SE B & Beta & B & SE B & Beta & B & SE B & Beta \\
\hline \multirow{2}{*}{ Constant } & - & \multirow{2}{*}{1.11} & & - & 7.78 & & - & 10.43 & \\
& 1.608 & & & 12.616 & 7 & & 18.09 & 9 & \\
\hline
\end{tabular}


Investment in software and consulting for electronic accounting

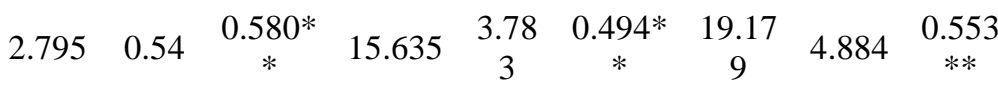

(VI01)

Type of firm (VI02):

\begin{tabular}{|c|c|c|c|c|c|}
\hline Dummy 1 & 3.749 & $\begin{array}{c}1.38 \\
2\end{array}$ & $0.292^{*}$ & & \\
\hline Dummy 2 & 3.748 & $\begin{array}{c}1.17 \\
1\end{array}$ & $\begin{array}{c}0.365 * \\
*\end{array}$ & & \\
\hline $\mathrm{R} 2$ & & 0.602 & & 0.244 & 0.306 \\
\hline R2 adjusted & & 0.57 & & 0.229 & 0.286 \\
\hline $\mathrm{F}$ & & $18.642 * *$ & & $17.077 * *$ & $15.419 * *$ \\
\hline No. Observations & & 40 & & 55 & 37 \\
\hline
\end{tabular}

The variability in the number of clients that sent the electronic accounting on time for the year 2015 (VD01) is significantly correlated (57\%, $\mathrm{R}^{2}$ adj=0.57, $\left.\mathrm{F}(2,37)=18.64, \mathrm{p}<0.001\right)$ with investment in software and consulting for electronic accounting (VI01) and for the type of firm (VI02), the type of firm is a categorical variable that made the use of two dummy variables necessary, the resulting estimated regression equations are:

For type of firm:

Natural Persons: $\quad$ Dummy $1=0$, and Dummy $2=0$

$$
\mathrm{VD} 01=-1.61+2.80(\mathrm{VI} 01)
$$

Businesses: Dummy1 $=1$ and Dummy2 $=0$

$$
\text { VD01 }=2.14+2.80 \text { (VI01) }
$$

Both: $\quad$ Dummy1 $=0$ y Dummy2=1

$$
\text { VD01=2.14+2.80 (VI01) }
$$

Of the variability of the number of clients who did not send their electronic accounting on time in 2015 (VD02) $\left(\mathrm{R}^{2}\right.$ adj $=0.23, \mathrm{~F}(1,53)=17.08$, $\mathrm{p}<.01) 23 \%$ is explained by investment in software and consulting for electronic accounting (VI01), the estimated regression equation is: VD02 = 12.62+15.64 (VI01).

The variable whether they are ready to send electronic accounting in 2016 (VD03) is explained by $(29 \%)\left(\mathrm{R}^{2} \operatorname{adj}=0.29, \mathrm{~F}(1,35)=17.08, \mathrm{p}<.01\right)$ investment in software and training in electronic accounting, regression is: VD03 $=-18.09+19.18$ (VI01) (Discovering Statistics Using IBM SPSS Statistics, 2013). 


\section{Conclusion}

We undertook this study to describe and explain the aspects related to the application of electronic accounting in Mexico. For this study, we employed a questionnaire to accounting firms in the state of Guanajuato, México. The accounting firms must submit their clients' accounting electronically to the Mexican Tax Authority (SAT). The questionnaire analyzed four factors: demographic profile of the firm, demographic profile of the director of the firm, training and investment in software and reasons for using electronic accounting, each one integrated with their respective variables.

The results show that almost all of the firms interviewed are constituted under the legal structure of natural persons, with an average of 17 years of accounting experience. The directors of these firms are typically male with master's degrees, almost all belong to a professional accounting institute, and a high percentage have received both professional training and training in electronic accounting. These factors contribute favorably; given that they constitute prior facilitating factors for the process of migrating to electronic accounting.

Our findings agree with Casanovas (2013) who comments that companies with general directors who are trained in the main function of the company may more easily adapt to a new working model. That is to say, accounting firms that have leaders who are specialized in the area of fiscal accounting will be those who have greater success in the implementation of electronic accounting.

The majority of the firms studied have not invested more than 40,000 MXN (2,000 USD) in software and consulting for the process of adoption of electronic accounting (e-accounting). The low cost may explain why the cost of conversion is not a factor that may be considered a difficult obstacle to overcome. Méndez (2009) sustains that the application of information technologies has two principal effects, on the one hand, it is a faster form of record-keeping that results in up-to-date information, and on the other hand, it facilitates the transfer of information to externals such as providers, clients, and regulating bodies. It is thought that cloud-based accounting systems facilitate online record-keeping of the information.

According to the information published on the websites of the three most commonly-used software companies among the Mexican accounting community. ERP (Enterprise Resource Planning) has two business models, one that operates through a local service provider and one that functions in the cloud, where the investment cost is significantly less than via the local service provider. However, it should be noted that for comparative purposes we assumed that every firm surveyed incurred an annual renewal cost, even if the initial investment was greater with the local service provider. 
Electronic accounting has been obligatory in Mexico since 2014. However, submitting the information was not required until 2015. In other words, all the firms with a local service provider were already using the basic accounting software before the obligation of submitting the information came into force. When we look at the cloud option, there is no difference between the initial cost and the cost of updating, as by its very nature of comprehensive design and functioning the cost is the same in the two modalities of initial adoption or renewal. The analysis concludes that the results obtained are coincident, as the costs incurred for the companies to adopt or update their software coincide with the prices that the companies offer on the market, which is evidence that proves the importance of this variable on the results of the study.

In the results of the regression analysis we found a high correlation with the variable investment in software and consulting, as it significantly contributes to the three models found and the type of firm is only significant to one. The first model affirmed that investment in software and training positively influenced submitting electronic accounting on time in 2015, and the expense of software or training was no impediment.

With regards to the type of firm, which is the second variable that contributes in a significant way to the regression model, we conclude that either of the modalities of the variable, natural persons or company, are correlated to the timely submission of accounting information, but due to the type of variable it is not possible to establish any other consideration in terms of expedience in any legal sense.

The second model refers to firms that did not comply with the obligation to send the accounting of their clients in 2015, the significant variable was investment in software in the regression analysis, explaining a little more than a fifth of the model. This must be related to the fact that those firms who did not comply, did not foresee the changing situation, they had no knowledge of the implications in terms of the funding necessary for implementation, or their reaction was too late to deal with the process. At the same time the above was due to not keeping up with the fiscal reform, lack of knowledge in terms of information technology and the changes necessary in their systems, staff training, and consequently the funds necessary to invest and comply with the changes implemented by the Mexican tax authority.

The theory of innovation diffusion by Rogers considers five stages for the adoption of an innovation, which is sequential and requires a period of time to complete each stage: knowledge, persuasion decision, implementation, and confirmation. According to this theory, the firms started the process with a perspective that fits into one of the following five categories of adopters: innovators, first adopters, early majority, the late majority, and last adopters. From this perspective, accounting firms did not complete the five steps 
opportunely, which is related to the perspective they had at the start of the adoption process, the resources that are destined to fulfill them, and the speed with which they transfer knowledge to confirmation. Evidently, those who were not efficient and effective did not meet their deadlines in 2015.

For the third model of accounting firms that are ready to submit their clients' electronic accounting in 2016, the same considerations as above apply, which may be confirmed by the results of the study. The variable investment in software and consulting had a positive and significant correlation that explained $30 \%$. Considering that for both groups that send the electronic accounting in 2015 and those obliged to send in 2016, the start dates were the same and the second group had a greater length of time to comply, so it is reasonable that it be related to a greater compliance, now that "they are ready to send in 2016 " they have already transitioned through the five steps stated in Rogers' theory.

The importance of electronic accounting acquires greater relevance due to its generalized use in an obligatory way, as there is no information from previous studies or research in this field, for the obvious reason that Mexico is the first country in the world to impose this kind of reform, which is why this study contributes to filling the void on the subject of the adoption of electronic accounting in Mexico.

For the Mexican firms who can comply with this new obligation, they must adapt their accounting systems so as to be able to train the staff in charge of elaborating the accounting information of the companies who offer services. If the Mexican government took this measure to speed up and improve tax collection, there are diverse elements that make opportune and correct compliance difficult, due to the administrative expenses that are involved in a firm setting up this kind of innovation.

This study helps the international community understand how the process has developed in Mexico in the implementation of electronic accounting; the principal advances and problems experienced, and furthermore what serves as an antecedent for those countries that may in future, following the international trends, adopt the use of electronic accounting in accounting firms.

Finally, it is convenient to indicate the limitations that dealing with a descriptive study include, the dimensions, and variables, taking into account previous studies in countries where adoption is not obligatory, and the authors consider applicable to the Mexican context. Being a new study for the reasons already described, we limited the comparisons under similar conditions of tendencies and wider relationships.

Future research should be undertaken with a larger sample to be able to generalize results. Future studies must allow us to validate the findings of this work and to undertake further improvements, eliminating and modifying 
the dimensions, variables, and items elaborated, in such a way that it allows us to establish cause and effect relationships, such as forming and applying new instruments that contribute to resolving the problems that this reform presents in reality.

\section{References:}

1. Amidu, M., John, E., \& Abor, J. (2011). E-Accounting Practices among Small and Medium Enterprises in Ghana. Journal of Management Policy and Practice, 145-155.

2. Arias, C. (2002). Tendencias actuales de la contabilidad, algunas experiencias del banco de la república. Available at http://www.cemla.org/contabilidad/docs/ acp_8_Colombia-esp.pdf.

3. Cabrera, M. (2010). Propuesta de modelo de retención del talento como fuente de ventaja competitiva en los pequeños Despachos Contables. Tesis de Maestría. Instituto Politécnico Nacional. Escuela Superior de Comercio y Administración, Unidad Santo Tomás. Available at: http://tesis.ipn.mx/bitstream/handle/123456789/9785/miriam\%20lizet $\underline{\mathrm{h} \% 20 \text { cabrera.pdf? sequence }=1}$

4. Casanovas, A. (2013) Resistencia al cambio y conductas obstructivas. Serie de Cuadernos sobre cumplimiento lega 11l. KPMG Cutting through complexity. Available at: www.kpmg.com/ES/es/servicios/Abogados/Legal/.../CuadernosLegales-N11.pdf

5. Cifuentes, R. (2013). Retos y desafios para la contabilidad. Available at:

http://administracion.univalle.edu.co/Docentes/WebPages/Material/1 79/INTRODUCCION\%20A\%20LA\%20CONTADURIA\%20PUBLI CA/RETOS\%20Y\%20DESAFIOS\%20PARA\%20LA\%20CONTAD URIA\%20RCV\%20100413.pdf

6. Código Fiscal de la Federación. (2016). Congreso de la unión de México.

7. CONTPAQi (2016). CONTPAQi. Software empresarial fácil y completo.

https://www.contpaqi.com/CONTPAQi/index.aspx

8. Crol PFF (2016). Plataforma de Servicios Financieros y Fiscales. Available at https://www.pff.mx/

9. Daoud, H. \& Triki, M. (2013). Accounting Information Systems in an ERP Environment and Tunisian Firm Performance. The International Journal of Digital Accounting Research. Vol. 13, 2013, pp. 1 - 35 ISSN: 1577-8517. 
10. Discovering Statistics Using IBM SPSS Statistics. (2013). Andy Field. 4th Edicion. Editorial Sage Publications Lt. ISBN: 9781446249185.

11. Drew, J. (2015). Accounting firms moving slowly toward cloud. Journal of Accountancy, 1-6.

12. Instituto Nacional de Estadística y Geografía (INEGI). Accessed 3003-2016, available at http://www3.inegi.org.mx/sistemas/mapa/denue/Cuantificar.aspx.

13. Lendel Hittmára y Siantová, V. a. (2014). Management of Innovation Processes in Company. Procedia Economics and Finance, 867-866.

14. López, M., López, M. y González N. (2014). Manual de organización aplicado a un Despacho Contable a través de la consultoría de negocios. El buzón de Pacioli. Revista del departamento de contaduría y finanzas publicada en el Instituto Tecnológico de Sonora. (86, 4-15). Available at:

15. http://www.itson.mx/publicaciones/pacioli/documents/no86/pacioli86.pdf

16. Martínez, M. (2004). Proceso, antecedentes y consecuencias de la adopción de innovaciones contables; contrastación de un modelo integrador. Cuadernos de Economía y Dirección de la Empresa. (21), 005-026. Available

https://www.google.com.mx/url?sa=t\&rct=j\&q=\&esrc=s\&source=we b\&cd=2\&cad=rja\&uact=8\&ved=0ahUKEwj57PLuhuzLAhUjsoMK HY iAtwQFggiMAE\&url=https\%3A\%2F\%2Fdialnet.unirioja.es\%2 Fdescarga\%2Farticulo\%2F1143436.pdf\&usg=AFQjCNGkN9ecVzP5jBXbcPZBXhjm3beDg\&sig2=1FbKPHyva9dtOTw-4pSyA\&bvm=bv.118443451,d.amc

17. Maza, P. (1997). Reflexión sobre las causas de la mortandad de la micro y pequeña empresa. 90-91.

18. Méndez, T (2007). Impacto de las TIC en la información contable empresarial. Available

at https://intranet.ebc.edu.mx/contenido/faculty/archivos/tic.pdf

19. Microsip (2016). Microsip. El software confiable de México. Available at http://www.microsip.com/CONSULTORES.aspx

20. Núñez, A. (2013). Análisis del Impacto en el Uso de los Sistemas de Información en los Despachos Contables de la Región Xalapa. Tesis de licenciatura publicada. Universidad Veracruzana, Xalapa-Enríquez, Veracruz, México.

21. Organización para la Cooperación y el Desarrollo Económicos (2012). Getting It Right. Una agenda estratégica para las reformas en México. OECD Publishing.

22. Okab, R. \& Ali Al-Oqool, M., (2014). The Role of Accountants in Eaccounting Information System's Lifecycle at the Jordanian Banking 
Sector. International Journal of Business and Social Science. Vol.5. No. 4.

23. Reglamento del Código Fiscal de la Federación. (2016). Congreso de la unión de México.

24. Rodríguez, M. (2003). LA CONTABILIDAD Y EL IMPACTO DE LAS TECNOLOGÍAS DE LA INFORMACIÓN Y LAS COMUNICACIONES. La contabilidad y el impacto de las tecnologías de la información y las comunicaciones. Contabilidad y Auditoría. Número $19 . \quad$ Available at: ojs.econ.uba.ar/ojs/index.php/Contyaudit/article/viewFile/144/234.

25. Rogers, E. M. (2003). Diffusion of innovations. New York: The Free Press.

26. Servicio de Administración Tributaria (SAT) Accessed 30-03-2016, available at http://www.sat.gob.mx/fichas_tematicas/buzon_tributario/Paginas/co ntabilidad_electronica.aspx

27. Tarmidi, M., Abdul S.Z., Alrazia, B., Abdul R. (2014). International Conference on Accounting Studies 2014, ICAS 2014, 18-19 August 2014, Kuala Lumpur, Malaysia. Available at: http://www.sciencedirect.com/science/article/pii/S187704281405967 $\underline{9}$ 